\title{
Pawel Głodek
}

Uniwersytet Łódzki

e-mail: glodek@uni.lodz.pl

\section{ZAUFANIE A ŹRÓDŁA DORADZTWA MAŁEJ FIRMY}

\section{TRUST VS. BUSINESS ADVICE PROVIDERS FOR A SMALL FIRM}

DOI: $10.15611 / \mathrm{pn} .2017 .489 .11$
JEL Classification: M13, M19

Streszczenie: W niniejszym artykule skoncentrowano się na problematyce wykorzystania zaufania w ramach umów doradztwa biznesowego dla małych firm. Analiza została przeprowadzona przy użyciu wyników badania 400 małych firm działających w Polsce, które korzystały $\mathrm{z}$ zewnętrznych porad biznesowych $\mathrm{w}$ ciągu ostatnich trzech lat przed badaniem. Jej wyniki wskazują na istotną rolę zaufania w ramach realizacji działań doradczych, niemniej wskazano też na zasadnicze różnice w odniesieniu do poszczególnych źródeł doradztwa oraz do rodzajów zaufania. Zauważono koncentrację na zaufaniu wynikającym z relacji osobistych przy znacząco mniejszym znaczeniu wcześniejszych doświadczeń doradztwa. Zidentyfikowano ponadto relatywnie wysoki udział relacji formalnych, w całości bazujących na umowach pisemnych. Nie są one typowe dla wyników badań uzyskanych w innych krajach UE.

Słowa kluczowe: mała firma, doradztwo biznesowe, zaufanie, źródła doradztwa.

Summary: The analysis in the article focuses on the extent to which trust is used in contracting business advice services by various advice providers for small firms. The analysis was carried out using the results of a study of 400 small companies operating in Poland which had used the external business advice in the last three years before the survey. Its results indicate a significant role for trust in the implementation of advisory activities. On the other hand, a high proportion of formal relationships has been identified that are not typical of research results obtained in other EU countries.

Keywords: small firm, business advice, trust, business advice providers.

\section{Wstęp}

Małe firmy posiadają szereg specyficznych charakterystyk rynkowych, finansowych, organizacyjnych i technologicznych, różniących je od dużych przedsiębiorstw. Stąd też mała firma nie powinna być uważana za „,przeskalowaną” czy też pomniejszo- 
ną wersję dużej firmy [Storey 1990]. Specyficzne zachowania można obserwować także w zakresie wykorzystywania unikalnych dla siebie źródeł wiedzy i małej formalizacji swoich działań.

Doradztwo gospodarcze jest uważane za jedno ze źródeł wiedzy istotnych z punktu widzenia budowania konkurencyjności małych przedsiębiorstw. Przy czym wskazywanych jest szereg problemów związanych z wykorzystaniem doradztwa, należą do nich z jednej strony czynniki finansowe, jak np. koszty doradztwa, które mogą stanowić znaczące wydatki w kontekście budżetów, jakimi dysponują małe firmy, a z drugiej strony czynniki miękkie odnoszące się do kontroli nad procesem doradczym. W tym kontekście podnoszone jest znaczenie zaufania jako czynnika sprzyjającego efektywnemu transferowi wiedzy, a również umożliwiającego zapoczątkowanie relacji doradczej.

Zaufanie może być także postrzegane w kontekście doradztwa jako mechanizm kontroli relacji, alternatywny do formalnego kontraktu. Przy wysokim poziomie zaufania możliwe jest obniżenie kosztów obsługi zlecenia doradczego oraz znaczące zwiększenie elastyczności procesu doradczego, umożliwiające jego dostosowanie stosownie do ujawnianych problemów działania firmy. Ponadto wykorzystanie mechanizmu pomijającego działania formalne zbieżne jest $\mathrm{z}$ charakterystykami działania znaczącej części małych firm.

Źródła doradztwa małych firm charakteryzują się jednak znaczącą niejednorodnością, tak więc celem niniejszego artykułu jest analiza stopnia zaufania w korzystaniu $\mathrm{z}$ usług doradztwa gospodarczego w odniesieniu do różnych źródeł doradztwa dla małych firm. Jej realizacja nastąpi z wykorzystaniem wyników badania 400 małych przedsiębiorstw prowadzących działalność w Polsce, które korzystały z doradztwa w ostatnich trzech latach przed badaniem.

\section{Mała firma i źródła doradztwa biznesowego}

W polityce gospodarczej kategorie małych (i mikro) firm wydziela się głównie na podstawie kryteriów ilościowych ${ }^{1}$, odnoszących się do liczby zatrudnionych, czy też czynników finansowych. W literaturze przedmiotu znaczącą rolę odgrywają jednak czynniki jakościowe, które wiążą się ze specyfiką zachowań organizacyjnych i strategicznych małych przedsiębiorstw.

Jedną z kluczowych cech małych firm jest powiązanie własności przedsiębiorstwa z bieżącym zarządzaniem. Przedsiębiorca, lub też zespół przedsiębiorców, posiada władzę związaną, wynikającą z obu aspektów. W konsekwencji możliwość oddziaływania przedsiębiorcy na firmę wykracza daleko poza aspekty formalne. Chodzi także o wpływ indywidualnych czynników osobowościowych czy socjologicznych,

\footnotetext{
${ }^{1}$ Porównaj zapisy Ustawy z dnia 2 lipca 2004 r. o swobodzie działalności gospodarczej, Dz.U. z 2004, nr 173, poz. 1807 z późn. zm., zawierającej definicje mikro, małych oraz średnich przedsiębiorców zbieżne z zaleceniem Komisji 2003/361/WE, opublikowanym w Dzienniku Urzędowym Unii Europejskiej L 124 z dnia 20 maja 2003, s. 36.
} 
które oddziałują na sposób funkcjonowania firmy, w tym nastawienie do m.in. ryzyka, sposobu oceny okazji rynkowych, rozwoju firmy. Z tego względu małe firmy są w literaturze nawet określane jako ,emocjonalne jednostki gospodarcze” [Dexter, Behan 1999]. Uważa się, że kreują one idiosynkratyczną kulturę, będącą pod wpływem cech osobowych przedsiębiorcy i silnie związaną z nieformalną komunikacją [Storey 1994; Cagliano i in. 2001; Mazzarol 2011]. Tak więc procesy podejmowania decyzji w małej firmie zwykle pozbawione są formalizacji, a ponadto są znacząco uzależnione od relacji zaufania z partnerami i oparte na podejściu holistycznym [Gibb 2000]. Dalley i Hamilton [2000] wskazują ponadto, że decyzje i działania właściciela-przedsiębiorcy są ukształtowane przez motywację do bycia niezależnym, intuicję i dążenie do osobistej zgodności w ramach relacji pomiędzy członkami zespołu zarządzającego małą firmą.

Zarządzający małą firmą rzadko dysponują całą wiedzą niezbędną do efektywnego i prowadzonego z sukcesem biznesu [Hutchinson, Quintas 2008], ponadto zakres potrzebnej wiedzy zmienia się wraz z rozwojem przedsiębiorstwa. Tak więc dostęp do zewnętrznych zasobów wiedzy może stać się jednym z czynników wpływających na sposób działania przedsiębiorstwa oraz możliwość i sposób jego rozwoju. Wykorzystanie wiedzy zewnętrznej może odegrać pozytywną rolę w procesie osłabiania barier rozwoju i redukcji postrzeganego ryzyka, związanego z podejmowaniem decyzji przez małe firmy [Głodek, Łobacz 2013].

Potrzebna i deficytowa wiedza może zostać pozyskana z otoczenia w różnej formie, w tym w formie doradztwa. Może ono zostać wykorzystane przez małą firmę jako wsparcie dla zarządzającego przy realizowaniu celów biznesowych, w zakresie problemów w sferze zarządzania, identyfikowania i wykorzystywania okazji rynkowych, uczenia się i wdrażania zmian [Yusuf 2010; Ajmal i in. 2009].

Doradztwo gospodarcze wykazuje zróżnicowanie w odniesieniu do zawartości usług świadczonych przedsiębiorstwom różnych rozmiarów, będących na różnych etapach rozwoju [Mole i in. 2013]. W tym kontekście wskazuje się na znaczącą specyfikę małych przedsiębiorstw również w odniesieniu do wykorzystywanych źródeł doradztwa. Wskazuje się, że właściciele małych przedsiębiorstw wykazują skłonność do bardzo częstego wykorzystywania różnego typu doradców spoza grona profesjonalnych firm doradczych oraz zawodowych doradców [North i in. 2011; Soriano, Castrogiovanni 2012]. Odnosi się to do przyjaciół, członków rodziny czy innych osób należących do kręgu znajomych, ale także osób i podmiotów, które są powiązane relacjami biznesowymi (ale nie bezpośrednio doradczymi), np. księgowych, dostawców, pracowników banku, klientów/odbiorców czy też partnerów handlowych [Blackburn, Jarvis 2010]. Doradztwo pochodzące od ekspertów niezawodowych jest szczególnie często wykorzystywane przez firmy nowo założone (do trzech lat działalności) oraz firmy znajdujące się w okresie różnego typu transformacji [North i in. 2011]. Ponadto grupą firm, która wykazuje wysokie wykorzystanie doradztwa niezawodowego, są firmy rodzinne [Strike 2012], co odnosić można do generalnie wysokiego wykorzystania relacji opartych na zaufaniu osobistym i relacjach osobistych w tej grupie firm. 
Pomimo szerokiej oferty, a także dużego wsparcia publicznego skierowanego na rozwój sektora, badania usług doradczych wskazują na występowanie szeregu problemów we współpracy doradców z firmami. Wiele z nich powiązanych jest z czynnikami osobowościowymi [Adamson 2000]. Innym elementem jest zagadnienie ryzyka korzystania z usług doradcy zewnętrznego. Odnosi się ono m.in. do ryzyka podejmowania przez doradcę działań niepożądanych na podstawie zdobytej wiedzy na temat firmy, w tym ujawnienia ich na zewnątrz, ponadto jest też związane z trudnością w ocenie jakości oferowanej usługi doradczej na początku relacji.

Łobacz i inni [2016], analizując przypadki głębokiego doradztwa dla małych firm, wskazują, że zaufanie należy do głównych elementów powiązanych z wykorzystaniem doradztwa przez małe firmy. Brak zaufania zasadniczo wyklucza nawiązanie głębszej relacji doradczej i realizację procesu transferu wiedzy oraz jej absorpcji.

\section{Zaufanie w kontekście doradztwa dla małych przedsiębiorstw}

Zaufanie jako pojęcie nie posiada jednolitej definicji, mimo że wykorzystywane jest ono w szeregu dyscyplinach nauki, spójności nie należy oczekiwać nawet w ramach poszczególnych obszarów [Walter, Smallbone 2006]. Niemniej w odniesieniu do relacji biznesowych koncepcja zaufania jest wiązana z postrzeganiem prawdopodobieństwa, że dany podmiot zachowa się w sposób, który jest od niego oczekiwany [Gambetta 1988]. W takim podejściu zaufanie może występować jako forma kontroli relacji. Kontrola ma wymiary dotyczące wykonania produktu oraz ceny produktu. Klient powinien być przekonany, że wykonawca w sposób właściwy wykonuje produkty i że cena, jakiej za nie żąda, jest odpowiednia [Heiskanen i in. 2008]. Kontrola zwiększa prawdopodobieństwo pozytywnego wyniku projektu.

W tym ujęciu zaufanie może występować jako forma kontroli alternatywna wobec kontraktu formalnego, w którym są określone obowiązki obu stron i konsekwencje niewywiązania się ze zobowiązań. Kontrakt formalny ułatwia dochodzenie roszczeń oraz rozwiązanie ewentualnych nieporozumień pomiędzy stronami. Z drugiej strony może ograniczać elastyczność kontraktu w przypadkach, gdy nie wszystkie jego elementy mogą być szczegółowo określone „z góry”.

W odniesieniu do doradztwa biznesowego jednym z czynników ograniczających zaufanie może być ryzyko podejmowania działań niepożądanych na podstawie zdobytej wiedzy na temat firmy, w tym ujawnienia ich na zewnątrz. W innym przypadku część właścicieli-przedsiębiorców może okazywać brak zaufania odnoszący się do odpowiedniej jakości oferowanej usługi [Scott, Irwin 2009; North i in. 2011], co niesie za sobą ryzyko braku oczekiwanych efektów oraz straty zasobów zaangażowanych w doradztwo (w tym czasu przedsiębiorcy). Tak więc czynniki ryzyka wiązane są z dwoma nieco odmiennymi obszarami ryzyka, tj. ryzykiem podejmowania działań sprzecznych z interesem firmy oraz ryzykiem niedostatecznego poziomu profesjonalnego samej usługi doradczej. 
W środowisku opartym na kontraktach krótkoterminowych trudno jest wypracować trwałe zaufanie. Jednak stosowanie szczegółowych metod kontroli, m.in. audytu czy kontroli jakości, nie sprzyja procesowi budowania wzajemnego zaufania [Gasik 2013]. Występuje więc pewnego rodzaju sprzeczność pomiędzy procesem budowy zaufania a wprowadzaniem formalnych metod kontroli. Niemniej Bresnen [2007] twierdzi, że w pewnym zakresie te czynniki mogą współistnieć, i sugeruje, że w rzeczywistości te obie formy zachowania powinny współistnieć.

W przypadku relacji doradztwa małe firmy mają więc możliwość kontroli kontraktu w postaci relacji zaufania, kontraktu formalnego albo też form uwzględniających oba sposoby. Niemniej analiza literatury odnosząca się do sposobu działania małych przedsiębiorstw skłania do założenia, iż nastawienie właścicieli małych przedsiębiorstw, preferujące zachowania nieformalne, sprzyjać będzie występowaniu wysokiego poziomu wykorzystania nieformalnych mechanizmów kontroli relacji doradztwa, bazujących na zaufaniu. Ze względu na zróżnicowanie doradztwa dla małych przedsiębiorstw można założyć, że wykorzystanie zaufania będzie szczególnie wysokie w odniesieniu do źródeł doradztwa wykorzystujących relacje osobiste z przedsiębiorcą.

\section{Charakterystyka badań. Metodologia}

Badaniem wykorzystanym w ramach niniejszego opracowania objęto małe przedsiębiorstwa o zatrudnieniu do 49 osób. Zostało ono przeprowadzone metodą wywiadów bezpośrednich telefonicznych wspomaganych komputerowo (CATI) z wykorzystaniem formularza ankietowego ${ }^{2}$. W celu pozyskania oryginalnych danych na temat przedmiotu badania ankieterzy poddali badaniu jedynie osoby bezpośrednio zarządzające firmami. Wykluczona została możliwość wypełnienia kwestionariusza przez osobę zatrudnioną, niebędącą właścicielem małej firmy. Umożliwiło to realizację wielu scenariuszy wywiadów w zależności od występowania zjawisk kluczowych dla przedmiotu badania. Wywiadami objęto firmy, które w trzech kolejnych latach poprzedzających badanie prowadziły działalność innowacyjną i korzystały z doradztwa biznesowego. Badania przeprowadzono w okresie czerwiec-sierpień 2016 roku. W celu zachowania wysokiej jakości badania wszystkie wywiady zostały nagrane, co umożliwia weryfikację sposobu ich przeprowadzenia oraz zgodności z założeniami metodologicznymi.

W metodologii badań założono, iż próba będzie liczyć 400 podmiotów gospodarczych z sektora krajowych mikro i małych firm wybranych losowo przy pomocy generatora liczb losowych z grupy 9703 firm z bazy REGON GUS. Wywiad ,właściwy" realizowano jedynie z firmami spełniającymi wszystkie wymogi ramowe. Po analizie kompletności uzyskanych danych i ich spójności przyjęto do analizy

\footnotetext{
${ }^{2}$ Badania przeprowadzono w ramach projektu sfinansowanego ze środków Narodowego Centrum Nauki przyznanych na podstawie decyzji nr DEC-2012/07/B/HS4/03019.
} 
syntetycznej wyniki dotyczące 400 firm. Współczynnik odpowiedzi (response rate) wyniósł 14,5\%, zaś współczynnik skuteczności 4,1\%.

\section{Wyniki badań}

Osobom uczestniczącym w badaniu zadano pytanie dotyczące zakresu wykorzystania umowy pisemnej w odniesieniu do najważniejszego doradztwa, z którego skorzystali w ostatnich trzech latach. Założono, że respondenci, jako osoby uprawnione do podejmowania decyzji w małych firmach, którymi zarządzają, posiadają dokładne informacje o tym zagadnieniu.

Odpowiedzi udzielone przez respondentów (patrz tabela 1) wskazują na znaczący udział relacji doradczych (35,3\%), które nie posiadały żadnej formy pisemnej i - co za tym idzie - polegały jedynie na ustaleniach ustnych. Nieco tylko wyższy udział odpowiedzi $(37,3 \%)$ wskazuje na przypadki doradztwa w całości objęte umową pisemną, bez udziału ustaleń ustnych. Przypadki doradztwa, które wykorzystywały obie formy umów, stanowiły łącznie 27,3\% odpowiedzi. Podsumowując, należy podkreślić, że zdecydowaną większość przypadków stanowiło doradztwo, w którym w mniejszym lub większym stopniu wykorzystano w umowach elementy ustaleń ustnych $(62,7 \%)$.

Tabela 1. Wykorzystanie pisemnej umowy w ramach zarządzania kontraktem doradczym w małych firmach

\begin{tabular}{|l|c|c|}
\hline \multicolumn{1}{|c|}{ Zakres wykorzystania umowy pisemnej } & Liczba firm & Udział proc. \\
\hline Nie było umowy pisemnej & 141 & 35,3 \\
\hline $\begin{array}{l}\text { Niewielka część objęta umową pisemną, a większość } \\
\text { pracy opierała się na ustaleniach ustnych }\end{array}$ & 57 & 14,3 \\
\hline $\begin{array}{l}\text { Większość zadań ujęta była w umowie pisemnej, } \\
\text { ale część ustaleń miała wyłącznie formę ustną }\end{array}$ & 52 & 13,0 \\
\hline Usługa w całości objęta była umową pisemną & 149 & 37,3 \\
\hline RAZEM & 399 & 100,0 \\
\hline
\end{tabular}

Dane dla 399 podmiotów.

Źródło: opracowanie własne.

Tabela 2 przestawia rozkład procentowy odpowiedzi respondentów dotyczących wykorzystania pisemnej umowy w ramach relacji doradczych w małych firmach przy uwzględnieniu rodzaju podmiotu świadczącego doradztwo 3 . Źródła doradztwa pogrupowano w sześć kategorii: (i) radca prawny, (ii) biuro księgowo-podatkowe, (iii) firma konsultingowa lub zawodowy niezależny konsultant, (iv) partner biznesowy,

${ }^{3}$ Analiza uzyskanych danych za pomocą testu chi-kwadrat wskazuje na pozytywną weryfikację hipotezy o zależności obu zmiennych na poziomie istotności 0,05 (wartość statystyki wynosi 58,99 przy 15 stopniach swobody). 
(v) członek rodziny lub znajomy oraz (vi) pozostałe podmioty (łącznie 10\% próby), w ramach których pojawiały się odpowiedzi wskazujące m.in. na doradców bankowych czy też instytucje wsparcia biznesu. Poszczególne firmy wskazywały jednego dostawcę doradztwa. W przypadku więcej niż jednego brano pod uwagę najważniejsze doradztwo z punktu widzenia właściciela.

Tabela 2. Wykorzystanie pisemnej umowy w ramach relacji doradczych w małych firmach w odniesieniu do rodzaju podmiotu świadczącego doradztwo (w \%)

\begin{tabular}{|l|c|c|c|c|c|}
\hline Źródło doradztwa & $\begin{array}{c}\text { Nie było } \\
\text { umowy } \\
\text { pisemnej } \\
\text { umowąść objęta } \\
\text { a większość } \\
\text { pracy opierała się, } \\
\text { na ustaleniach } \\
\text { ustnych }\end{array}$ & $\begin{array}{c}\text { Większość } \\
\text { zadań ujęta } \\
\text { była w umowie } \\
\text { pisemnej, ale } \\
\text { część ustaleń } \\
\text { miała wyłącznie } \\
\text { formę ustną }\end{array}$ & $\begin{array}{c}\text { Usługa } \\
\text { w całości } \\
\text { objęta była } \\
\text { umową } \\
\text { pisemną }\end{array}$ & Razem \\
\hline Radca prawny & 31,6 & 14,7 & 17,9 & 35,8 & 100,0 \\
\hline $\begin{array}{l}\text { Biuro księgowo- } \\
\text {-podatkowe }\end{array}$ & 37,7 & 12,3 & 11,0 & 39,0 & 100,0 \\
\hline $\begin{array}{l}\text { Firma } \\
\text { konsultingowa/ } \\
\text { konsultant }\end{array}$ & 3,9 & 17,6 & 15,7 & 62,7 & 100,0 \\
\hline Partner biznesowy & 46,7 & 20,0 & 20,0 & 13,3 & 100,0 \\
\hline $\begin{array}{l}\text { Członek rodziny } \\
\text { lub znajomy }\end{array}$ & 61,1 & 16,7 & 8,3 & 13,9 & 100,0 \\
\hline Pozostałe podmioty & 45,0 & 7,5 & 5,0 & 42,5 & 100,0 \\
\hline Cała próba & 35,4 & 14,1 & 13,1 & 37,4 & 100,0 \\
\hline
\end{tabular}

Dane dla 398 podmiotów.

Źródło: opracowanie własne.

Struktura odpowiedzi dotycząca korzystania z doradztwa radców prawnych oraz biur księgowo-podatkowych jest znacząco zbliżona do struktury całej próby. Znacząco odmienne są wskazania dotyczące pozostałych kategorii. W przypadku korzystania z podmiotów zawodowo dostarczających usług doradczych (poza poradami prawnymi oraz księgowymi) zdecydowana większość umów miała formę pisemną $(62,7 \%$, tj. o 25,3 punktu procentowego niż wskaźnik dla całej próby), natomiast niemal żadna z firm nie zdecydowała się wyłącznie na formę ustną umowy (3,9\%). Odmienna sytuacja ma miejsce w odniesieniu do doradztwa świadczonego przez osoby/podmioty, które były również w innej relacji biznesowej z badanymi firmami. Tu niemal połowa badanych firm wskazała na brak umowy pisemnej $(46,7 \%$, tj. 11,3 punktu procentowego powyżej wskaźnika dla całej próby). Jeszcze większą różnicę odnotowano w przypadku doradztwa świadczonego przez członków rodzin lub osoby znajome. W tym przypadku znacznie ponad połowa badanych firm korzystała $\mathrm{z}$ doradztwa bez umowy pisemnej (61,1\%, tj. 25,7 punktu procentowego powyżej średniej dla próby). 
Tabela 3 przedstawia rozkład procentowy odpowiedzi respondentów dotyczących wykorzystania pisemnej umowy w ramach relacji doradczych w małych firmach przy uwzględnieniu głównego czynnika, który wpłynął na wybór doradcy ${ }^{4}$. Tak więc pod uwagę wzięto jedynie czynnik uznany przez przedsiębiorcę za najważniejszy. Najczęściej wskazywanymi czynnikami były: (i) dobre doświadczenie wynikające z wcześniejszej współpracy doradczej, (ii) doradca został polecony przez osoby trzecie, (iii) doradca został wybrany na podstawie wcześniejszej współpracy niezwiązanej z doradztwem, (iv) doradcą jest osoba znana z wcześniejszych kontaktów osobistych. Pozostałe wypowiedzi, ze względu na niską częstotliwość występowania, zgrupowano w kategorii ,inne”.

Tabela 3. Wykorzystanie pisemnej umowy w ramach relacji doradczych w małych firmach w odniesieniu do głównego czynnika wyboru podmiotu świadczącego doradztwo (w \%)

\begin{tabular}{|c|c|c|c|c|c|}
\hline $\begin{array}{l}\text { Kluczowy czynnik, } \\
\text { który wpłynął na } \\
\text { wybór konkretnego } \\
\text { doradcy }\end{array}$ & $\begin{array}{l}\text { Nie było } \\
\text { umowy } \\
\text { pisemnej }\end{array}$ & $\begin{array}{c}\text { Niewielka część } \\
\text { objęta umową } \\
\text { pisemną, } \\
\text { a większość } \\
\text { pracy opierała } \\
\text { się na } \\
\text { ustaleniach } \\
\text { ustnych }\end{array}$ & $\begin{array}{c}\text { Większość } \\
\text { zadań ujęta } \\
\text { była w umowie } \\
\text { pisemnej, } \\
\text { ale część } \\
\text { ustaleń miała } \\
\text { wyłącznie } \\
\text { formę ustną }\end{array}$ & $\begin{array}{l}\text { Usługa } \\
\text { w całości } \\
\text { objęta była } \\
\text { umową } \\
\text { pisemną }\end{array}$ & Razem \\
\hline $\begin{array}{l}\text { Dobre } \\
\text { doświadczenie } \\
\text { z wcześniejszej } \\
\text { współpracy } \\
\text { doradczej }\end{array}$ & 28,0 & 21,3 & 8,0 & 42,7 & 100,0 \\
\hline $\begin{array}{l}\text { Doradca polecony } \\
\text { przez osoby trzecie }\end{array}$ & 24,3 & 13,9 & 19,4 & 42,4 & 100,0 \\
\hline $\begin{array}{l}\text { Doradca wybrany } \\
\text { na podstawie } \\
\text { wcześniejszej } \\
\text { współpracy } \\
\text { niezwiązanej } \\
\text { z doradztwem } \\
\end{array}$ & 47,3 & 12,7 & 5,5 & 34,5 & 100,0 \\
\hline $\begin{array}{l}\text { Doradcą jest osoba } \\
\text { znana z kontaktów } \\
\text { osobistych }\end{array}$ & 67,9 & 11,3 & 5,7 & 15,1 & 100,0 \\
\hline Inne & 31,9 & 11,1 & 16,7 & 40,3 & 100,0 \\
\hline Dla całej próby & 35,3 & 14,5 & 13,0 & 37,3 & 100,0 \\
\hline
\end{tabular}

Dane dla 398 podmiotów.

Źródło: opracowanie własne.

${ }^{4}$ Analiza uzyskanych danych za pomocą testu chi-kwadrat wskazuje na pozytywną weryfikację hipotezy o zależności obu zmiennych na poziomie istotności 0,05 (wartość statystyki wynosi 48,24 przy 12 stopniach swobody). 
Struktura odpowiedzi wskazuje, że jeśli wybór doradcy został dokonany na bazie kontaktów osobistych istniejących przed procesem doradztwa, miało to istotny wpływ na ograniczenie wykorzystania umowy pisemnej. W takim przypadku aż ponad 2/3 odpowiedzi wskazuje na zupełny brak umowy pisemnej (67,9\%, tj. 32,6 punktu procentowego powyżej średniej dla całej próby), a umowa pisemna obejmowała większość lub całość warunków doradztwa jedynie w około jednej piątej przypadków (odpowiednio 5,7\% oraz 15,1\%). W sytuacji, gdy usługa doradcza została wybrana na podstawie wcześniejszej współpracy niezwiązanej z doradztwem, wówczas niemal połowa umów miała jedynie formę ustną $(47,3 \%, \mathrm{tj} .12$ punktów procentowych powyżej średniej dla próby). Z drugiej strony w przypadku korzystania z usług doradców poleconych przez osoby trzecie poziom wykorzystania jedynie umowy ustnej był znacząco niższy niż średnia dla próby $(24,3 \%$, tj. o 11 punktów procentowych poniżej średniej). Uzyskane wyniki w tych kategoriach są znacząco spójne z odpowiedziami w tabeli 2.

\section{Analiza rezultatów}

Uzyskane wyniki badania wskazują na znaczące zróżnicowanie postaw przedsiębiorców. Najwięcej wskazań osiągnęły zachowania krańcowe, z jednej strony wykorzystanie jedynie formy pisemnej, a z drugiej zupełny brak ustaleń pisemnych i wykorzystanie jedynie ustaleń ustnych. Zachowania pośrednie były deklarowane rzadziej. Co interesujące, odniesienie do wyników uzyskanych przez Bennetta i Robsona [2004] w ramach badania małych firm brytyjskich wskazuje na wysoką tendencję polskich przedsiębiorców do formalizacji kontraktów doradczych. We wskazanym badaniu jedynie 3,6\% badanych firm brytyjskich bazowało w większym stopniu na formalnym kontrakcie niż na ustaleniach ustnych. Tak więc stosowanie wyłącznie umowy pisemnej niemalże nie występowało w ramach badania brytyjskiego, przy porównywalnym stopniu oparcia umów jedynie na ustaleniach ustnych.

Wyniki badania wskazują na relacje osobiste jako środek transferu mechanizmu zaufania. Jest to widoczne szczególnie w zakresie doradztwa świadczonego przez osoby znane wcześniej z kontaktów osobistych, w tym osoby z kręgu rodziny lub znajomych. W tym przypadku stosowanie umowy opartej w przeważającym stopniu na formie pisemnej należy do rzadkości.

Zaufanie wykorzystywane jest na wysokim poziomie w przypadku osób/podmiotów znanych z wcześniejszych kontaktów zawodowych, ale nie dotyczących doradztwa. Odnosi się to do relacji doradczych świadczonych przez różnego typu partnerów biznesowych. Można założyć, że zaufanie w ramach doradztwa jest efektem zaufania wypracowanego wcześniej w ramach realizowanych wspólnie przedsięwzięć.

Co interesujące, rezultaty wskazują na niski poziom zaufania w odniesieniu do podmiotów, które świadczyły już wcześniej usługi doradcze dla danej firmy. Tak więc zwiększenie doświadczenia $\mathrm{w}$ tym zakresie wpływa na zwiększenie poziomu 
wykorzystania formy pisemnej umów doradczych. Ten rezultat wskazuje m.in. na skłonność do ograniczenia ryzyka ponownej współpracy przez przedsiębiorcę (lub doradcę), co może sugerować, że dotychczasowa współpraca nie przyczyniła się do zbudowania wzajemnego zaufania. Może to być spowodowane zarówno efektami współpracy, jak i nieporozumieniami przy jej realizacji. Możliwy jest również negatywny wpływ wcześniejszych doświadczeń podmiotów świadczących doradztwo, które wykorzystują formę pisemną, aby ograniczyć własne ryzyko powiązane np. $\mathrm{z}$ rozszerzaniem zakresu usług przez przedsiębiorcę bez dodatkowego wynagrodzenia.

\section{Wnioski}

Podsumowując analizę uzyskanych danych w kontekście literatury przedmiotu, należy wskazać, że zaufanie jako mechanizm kontroli stanowi istotny czynnik kontroli relacji doradczych. $\mathrm{Z}$ drugiej strony międzynarodowe porównania wskazują, że może być wykorzystywany w mniejszym stopniu niż w krajach o wyższym poziomie zaufania społecznego. Ze względu na tę różnicę oraz dużą skalę zagadnienia zakres i sposób wykorzystania mechanizmu zaufania w doradztwie powinien być poddany bardziej szczegółowej analizie. Szczególnie w kontekście niskiego poziomu zaufania w Polsce, występującego w całym społeczeństwie [Nowakowski 2008; CBOS 2012] i wpływającego na relacje biznesowe [Raport KRDiRF 2015].

Szczególnie interesującym kierunkiem dalszych badań jest wykorzystanie różnych rodzajów zaufania. Analiza wskazuje na koncentrację badanych przedsiębiorców na zaufaniu osobistym, wywodzącym się z relacji indywidualnych. W mniejszym zakresie wykorzystywane jest zaufanie budowane na wcześniejszej realizacji kontraktów doradczych. Może to być jednak również efektem doświadczeń partnerów małych firm. To właśnie doradztwo świadczone przez firmy konsultingowe charakteryzuje się zdecydowanie najwyższym stopniem wykorzystania kontraktów pisemnych.

Ze względu na duże wykorzystanie zaufania jako mechanizmu kontroli wydaje się, iż ten czynnik powinien być wzięty pod uwagę przy konstruowaniu instrumentów polityki wsparcia dla małych przedsiębiorstw. Wskazana jest analiza odnosząca się do tego, w jakim zakresie wykorzystanie mechanizmów opartych na formalnych kontraktach i procedurach (rozeznanie rynku, przetargi itp.) w ramach narzędzi wsparcia publicznego dla małych firm może wpływać na efektywność tegoż wsparcia. Wydaje się, że w odniesieniu do znaczącej części sektora ten rodzaj zachowań jest głęboko sprzeczny z ich sposobami postępowania.

\section{Literatura}

Adamson I., 2000, Management consultant meets a potential client for the first time: the pre-entry phase of consultancy in SMEs and the issues of qualitative research methodology, Qualitative Market Research: An International Journal, no. 3 (1), s. 17-26. 
Ajmal M.M., Nordstrom F., Helo P., 2009, Assessing the effectiveness of business consulting in operations development Project, International Journal of Productivity and Performance Management, no. 58 (6), s. 523-541.

Bennett R., Robson P., 2004, The role of trust and contract in the supply of business advice, Cambridge Journal of Economics, no. 28, s. 471-488.

Blackburn R., Jarvis R., 2010, The role of small and medium practices in providing business support to small- and medium-sized enterprises, raport z projektu badawczego, International Federation of Accountants, New York.

Bresnen M., 2007, Deconstructing partnering in project-based organisation: Seven pillars, seven paradoxes and seven deadly sins, International Journal of Project Management, no. 25, s. 365-374.

Cagliano R., Blackmon K., Voss Ch., 2001, Small firms under MICROSCOPE: international differences in production/operations management practices and performance, Integrated Manufacturing Systems, no. 12 (7), s. 469-482.

CBOS, 2012, Zaufanie społeczne. Komunikat z badań, CBOS, Warszawa, marzec.

Dalley J., Hamilton B., 2000, Knowledge, context and learning in the small business, International Small Business Journal, no. 18(3), s. 51-59.

Dexter A., Behan G., 1999, Small business consumers: The emotional economic unit, Journal of the Market Research Society, no. 41(2), s. 171-194.

Gambetta D., 1988, Can We Trust Trust?, [w:] Gambetta D. (red.), Trust. Making and Breaking Cooperative Relations, Blackwell, Oxford.

Gasik S., 2013, Zaufanie i partnerstwo jako alternatywa dla kontroli w projektach publicznych, http:// www.sybena.pl/dokumenty/Projekty-Publiczne/Zaufanie-i-partnerstwo-jakoalternatywa-dlakontroli-w-projektach-publicznych.pdf (22.04.2017).

Gibb A., 2000, SME Policy, Academic research and the growth of ignorance, mythical concepts, myths, assumptions. Rituals and confusions, International Small Business Journal, no. 18(3), s. 13-34.

Głodek P., Łobacz K., 2013, Model ryzyka w decyzjach strategicznych matych firm innowacyjnych, [w:] Urbanowska-Sojkin E., Bartkowiak P. (red.), Ryzyko w zarzadzaniu strategicznym, Wydawnictwo Uniwersytetu Ekonomicznego w Poznaniu, Poznań, s. 245-262.

Heiskanen A., Newman M., Eskin M., 2008, Control, trust, power, and the dynamics of information system outsourcing relationships: A process study of contractual software development, Journal of Strategic Information Systems, no. 17(4), s. 268-286.

Hutchinson V., Quintas P., 2008, Do SMEs do knowledge management? Or simply manage what they know?, International Small Business Journal, no. 26 (2), s. 131-154.

Łobacz K., Głodek P., Stawasz E., Niedzielski P., 2016, Utilisation of business advice in small innovative firms: The role of trust and tacit knowledge, Entrepreneurial Business and Economics Review, no. 4(2), s. 117-138, DOI: http://dx.doi.org/10.15678/EBER.2016.040210.

Mazzarol T., 2011, Entrepreneurship and innovation. Readings and cases, Tilde University Press.

Mole K.F., Baldock R., North D., 2013, Who takes advice? Firm size threshold, competence, concerns and informality in a contingency approach, ERC Research Paper, no. 9, September

North D., Baldock R., Mole K., Wiseman J., Binnie C., 2011, Research to Understand the Barriers to Take up and Use of Business Support, Report for the Department for Business Innovation and Skills, London.

Nowakowski K., 2008, Wymiary zaufania i problem zaufania negatywnego w Polsce, Ruch Prawniczy, Ekonomiczny i Socjologiczny, rok LXX, zeszyt 1, s. 213-233.

Raport KRDiRF, 2015, Kapitat spoteczny i zaufanie w polskim biznesie 2015, Raport Krajowego Rejestru Długów i Rzetelnej Firmy, https://krd.pl/getattachment/d31be7a8-50b9-47b7-aeb53ff09ce60c71/Kapita\%C5\%82-spo\%C5\%82eczny-i-zaufanie-w-polskim-biznesie-20.aspx?disposition=attachment (7.04.2017).

Scott J.M., Irwin D., 2009, Discouraged advisees? The influence of gender, ethnicity, and education in the use of advice and finance by UK SMEs, Environment and Planning C-Government and Policy, no. $27(2)$, s. 230-245. 
Soriano D.R., Castrogiovanni G.J., 2012, The impact of education, experience and inner circle advisors on SME performance: insights from a study of public development centers, Small Bussiness Economics, no. 38, s. 333-349.

Storey D.J., 1990, Firm Performance and Size, [w:] Acs Z.J., Audretsch D.B. (red.), The Economics of Small Firms. A European Challenge, Kluwer Academic Publishers, Dordrecht - Boston - London.

Storey D.J., 1994, Understanding Small Business Sector, Routledge, London.

Strike V.M., 2012, Advising the family firm: Reviewing the past to build the future, Family Business Review, no. 25(2), s. 156-177.

Ustawa z dnia 2 lipca 2004 r. o swobodzie działalności gospodarczej, Dz.U. z 2004, nr 173, poz. 1807 z późn. zm.

Walter F., Smallbone D., 2006, Exploring the role of trust in entrepreneurial activity, Entrepreneurship Theory and Practice, no. 30(4), s. 465-475.

Yusuf J.-E., 2010, Meeting entrepreneurs 'support needs: are assistance programs effective?, Journal of Small Business and Enterprise Development, no. 17(2), s. 294-307.

Zalecenie Komisji 2003/361/WE, opublikowane w Dzienniku Urzędowym Unii Europejskiej L 124 $\mathrm{z}$ dnia 20 maja $2003 \mathrm{r}$. 